\title{
Combination of Captopril and Allopurinol Retards Fructose-Induced Metabolic Syndrome
}

\author{
Carlos A. Roncal ${ }^{a, b}$ Sirirat Reungjui ${ }^{b, c}$ Laura Gabriela Sánchez-Lozada a, b, d \\ Wei Mu $^{\mathrm{b}}$ Yuri Y. Sautin ${ }^{\mathrm{b}}$ Takahiko Nakagawa ${ }^{\mathrm{a}} \mathrm{b}$ Richard J. Johnson ${ }^{\mathrm{a}, \mathrm{b}}$ \\ a Division of Renal Diseases and Hypertension, University of Colorado, Denver, Colo., and bivision of Nephrology, \\ Hypertension and Renal Transplantation, University of Florida, Gainesville, Fla., USA; 'Division of Nephrology, \\ Khon Kaen University, Khon Kaen, Thailand; 'D Department of Nephrology INC Ignacio Chávez, Mexico City, Mexico
}

\section{Key Words}

Uric acid $\cdot$ High fructose diet $\cdot$ Insulin resistance $\cdot$

Hypertension

\begin{abstract}
Background: Both ACE inhibitors and allopurinol have been shown to partially prevent metabolic syndrome induced by fructose. We tested the hypothesis that combined therapy might be more effective at blocking the metabolic syndrome induced with fructose. Methods: Male Sprague-Dawley rats were fed a high fructose diet with or without allopurinol, captopril, or the combination for 20 weeks. A control group received a normal diet. All groups were pair-fed to assure equivalent caloric intake. Results: Despite reduced energy intake, the fructose-fed rats developed features of metabolic syndrome including elevated blood pressure, abdominal obesity, hypertriglyceridemia, hyperuricemia and hyperinsulinemia. While both allopurinol and captopril alone tended to reduce features of the metabolic syndrome, the combined therapy was synergistic, with significant reduction in blood pressure, less accumulation of abdominal fat, an improvement in the dyslipidemia and a complete prevention of insulin resistance. Conclusion: A high fructose diet can induce metabolic syndrome even in the setting of
\end{abstract}

\section{KARGER}

\section{(c) 2009 S. Karger AG, Basel}

Fax +4161306 1234 E-Mail karger@karger.ch www.karger.com www.karger.com/ajn caloric restriction. Captopril and allopurinol synergistically reduce features of the metabolic syndrome, especially hypertension, insulin resistance and dyslipidemia. Combination allopurinol and ACE inhibitor therapy might provide a superior means to prevent diabetes and cardiovascular disease.

Copyright $\odot 2009$ S. Karger AG, Basel

\section{Introduction}

Currently, 26\% of the US adult population has the metabolic syndrome (MS) [1]. While debate exists over whether the MS carries better predictive value for cardiovascular disease than its components, there is consensus that the prevention of MS could be beneficial in reducing the frequency of diabetes and heart disease.

Recently, excessive intake of fructose from sugar and high fructose corn syrup has been proposed in the etiology of MS and the obesity epidemic [2-4]. If excessive fructose intake is a cause of MS, then restriction of fructose intake would be an ideal prevention. It is also impor-

\section{C.A. Roncal and S. Reungjui contributed equally to this paper.}

Dr. Richard J. Johnson

Division of Renal Diseases and Hypertension, University of Colorado

Box C281, 12700 East 19th Avenue, Research 2, Room 7015

Aurora, CO 80045 (USA)

Tel. +1 303724 4865, Fax +1 303724 4831, E-Mail richard.johnson@ucdenver.edu 
tant to identify therapeutics that block the metabolic effects of fructose.

Experimentally administering fructose to rats causes metabolic syndrome. Fructose induces MS in part due to its unique ability to raise intracellular and serum uric acid (UA) [5-7]. Lowering UA in fructose-induced MS lowered blood pressure, improved insulin sensitivity, and modestly reduced hypertriglyceridemia, likely by improving endothelial and adipocyte dysfunction [5, 8-11]. UA also activates the renin-angiotensin system (RAS) and blocking the RAS prevents some of the vascular effects of UA [12-15]. RAS inhibition has also been reported to reduce the incidence of type 2 diabetes $[16,17]$ and to reduce body weight [18] in various clinical trials.

It has been shown that other vasoactive substances also have a role in fructose-induced metabolic syndrome in rats [19]. For example, there is evidence that endothelin may act upstream of the RAS [20]. In fructose-fed rats treatment with bosentan prevented the development of hypertension and decreased the levels of angiotensin II, while treatment with an AT1 receptor antagonist significantly increased vascular endothelin [20]. Interestingly, it was recently demonstrated that UA significantly increases the expression of endothelin-1 in vitro, in cardiac fibroblasts and aortic VSMC $[21,22]$ as well as in vivo [23].

It is unknown whether angiotensin-converting enzyme (ACE) inhibitors and allopurinol provide similar protection against development of MS or whether the effects are synergistic. In this regard we hypothesize that combination therapy might be more effective since captopril blocks the RAS, whereas allopurinol may prevent endothelin-1 overexpression. Thus, the objective of the present work was to test whether combination treatment with captopril and allopurinol is superior to either agent alone in preventing fructose-induced MS.

We therefore tested the hypothesis that the combination of captopril and allopurinol is superior to either agent alone in preventing fructose-induced MS.

\section{Materials and Methods}

The study was approved by the University of Florida Institutional Animal Use and Care Committee.

Male Sprague-Dawley rats (250-300 g, Charles River, Wilmington, Mass., USA) were placed on a standard diet (Harlan, Madison, Wisc., USA) for a five day run-in period and then were divided into 5 groups $(n=8)$. Group $1(\mathrm{~N})$ : standard diet (containing $46 \%$ complex carbohydrate), $3.4 \mathrm{kcal} / \mathrm{g}$ (Harlan, Madison, Wisc., USA); group 2 (F): $60 \%$ fructose diet, $3.6 \mathrm{kcal} / \mathrm{g}$ (Harlan, Madison, Wisc., USA); group $3(\mathrm{~F}+\mathrm{A})$ : $60 \%$ fructose diet plus allopurinol
(Sigma, St. Louis, Mo., USA) $10 \mathrm{mg} / \mathrm{kg} /$ day dissolved in the drinking water; group $4(\mathrm{~F}+\mathrm{C})$ : $60 \%$ fructose diet plus captopril (Sigma) $10 \mathrm{mg} / \mathrm{kg} /$ day provided in the drinking water, and group 5 $(\mathrm{F}+\mathrm{C}+\mathrm{A}): 60 \%$ fructose diet plus the same doses of captopril and allopurinol.

The dose of allopurinol was selected as the optimal dose that does not cause nephrotoxicity [24-27]. The dose of captopril was a standard dose used in multiple studies [28-30].

Since ACE inhibitors significantly reduce caloric intake in rats [31], rats were pair-fed to assure equivalent caloric intake. Body weight and water intake were measured weekly. At week 14, after $4 \mathrm{~h}$ fasting, tail vein blood was collected for metabolic evaluation. HOMA-IR and QUICKI were calculated from fasting (17 h) glucose and insulin obtained at week 17. Rats were sacrificed at week 20 and intra-abdominal fat was excised and weighed.

\section{Metabolic Measurements}

Systolic blood pressure (SBP) was measured in conscious rats by tail-cuff sphygmomanometer (Visitech BP2000; Apex, N.C., USA) at week 7 [5]. Serum glucose, cholesterol, triglycerides, UA, blood urea nitrogen and creatinine were measured by autoanalyzer (VetAce; Alfa Wassermann, West Caldwell, N.J., USA).

The presence of insulin resistance was determined in fasting rats at 17 weeks by calculating HOMA-IR and QUICKI indices according to formulas described elsewhere [32]. These estimates of insulin resistance correlate with the standard hyperinsulinemic-euglycemic clamp method [33]. Serum insulin was measured by ELISA (Crystal Chem, Chicago, Ill., USA).

\section{Statistical Analysis}

All data are shown as mean \pm SD. One way ANOVA (SPSS 15.0) and post hoc multiple comparisons were used to determine the significance between the mean of multiple groups with the least-significant difference test for equal and Dunnett's test for unequal variances. The homogeneity of variance was clarified by Levene's test. The paired and unpaired Student t test was used to compare the continuous variables of the specific two groups. Pearson's correlation was used to address potential associations between groups. Statistical significance was defined as $\mathrm{p}<0.05$.

\section{Results}

\section{Effect of Diet and Pharmacological Treatments on}

Body Weight Gain

Rats were pair-fed to assure equivalent energy intake between groups. This was important since rats fed ACE inhibitors are known to reduce their energy intake [31]. Fructose diet groups received $21 \mathrm{~g} /$ day $(75.6 \mathrm{kcal} /$ day $)$ and normal control diet groups received $22.2 \mathrm{~g} / \mathrm{day}$ ( $75.5 \mathrm{kcal} /$ day), which is $20 \%$ less than the normal dietary intake we have historically observed [5]. Despite animals receiving the same energy intake, both captopril-treated groups $(\mathrm{F}+\mathrm{C}$ and $\mathrm{F}+\mathrm{C}+\mathrm{A})$ gained significantly less weight relative to fructose-fed rats (table 1 ). 
Table 1. Body weight, abdominal fat weight and metabolic parameters

\begin{tabular}{|c|c|c|c|c|c|}
\hline & $\mathrm{N}$ & $\mathrm{F}$ & $\mathrm{F}+\mathrm{A}$ & $\mathrm{F}+\mathrm{C}$ & $\mathrm{F}+\mathrm{C}+\mathrm{A}$ \\
\hline \multicolumn{6}{|l|}{ Body weight, g } \\
\hline Baseline & $294 \pm 22$ & $294 \pm 24$ & $294 \pm 21$ & $294 \pm 16$ & $294 \pm 23$ \\
\hline At sacrifice & $573 \pm 86$ & $614 \pm 70$ & $588 \pm 59$ & $536 \pm 36^{\#}$ & $532 \pm 56^{\#}$ \\
\hline Abdominal fat weight, $g$ & $19.5 \pm 10.5$ & $33.6 \pm 9.1^{*}$ & $34.0 \pm 7.6^{*}$ & $24.0 \pm 6.7^{\#, \&}$ & $19.9 \pm 7.9^{\#, \&}$ \\
\hline Abdominal fat weight/BW, g/100 g & $3.25 \pm 1.4$ & $5.43 \pm 1.2^{*}$ & $5.74 \pm 0.9^{*}$ & $4.44 \pm 1.0^{\&}$ & $3.65 \pm 1.1^{\#, \&}$ \\
\hline Serum triglycerides, $\mathrm{mg} / \mathrm{dl}$ & $124 \pm 45$ & $559 \pm 171^{*}$ & $434 \pm 200^{*}$ & $398 \pm 165^{*}$ & $256 \pm 66^{*, \#, \&, \$}$ \\
\hline Total cholesterol, mg/dl & $94 \pm 14$ & $125 \pm 21^{*}$ & $111 \pm 22$ & $109 \pm 19$ & $94 \pm 22^{\#}$ \\
\hline Serum glucose, $\mathrm{mg} / \mathrm{dl}$ & $179 \pm 22$ & $169 \pm 19$ & $162 \pm 20$ & $178 \pm 18$ & $175 \pm 13$ \\
\hline Serum UA, mg/dl & $2.13 \pm 0.3$ & $2.63 \pm 0.6^{*}$ & $1.95 \pm 0.3^{\#}$ & $2.23 \pm 0.5$ & $1.46 \pm 0.2^{*, \#, \&, \$}$ \\
\hline Serum insulin, $\mu \mathrm{IU} / \mathrm{ml}$ & $72.8 \pm 26$ & $110.3 \pm 40^{*}$ & $108.6 \pm 38^{*}$ & $104.7 \pm 31^{*}$ & $80.1 \pm 23$ \\
\hline
\end{tabular}

$\mathrm{N}=$ Normal group $\mathrm{F}=$ fructose group $\mathrm{F}+\mathrm{A}=$ fructose plus allopurinol group $; \mathrm{F}+\mathrm{C}=$ fructose plus captopril group $\mathrm{F}+\mathrm{C}+\mathrm{A}=$ fructose plus captopril plus allopurinol group. $\mathrm{p}<0.05^{*}$ vs. $\mathrm{N},{ }^{\#}$ vs. F, ${ }^{\&}$ vs. F + A, ${ }^{\$}$ vs. F + C.

High Fructose Diet Causes Metabolic Syndrome despite Energy Restriction

Despite restricted energy intake, fructose-fed rats developed metabolic syndrome. Total intra-abdominal fat and the ratio of abdominal fat to body weight were increased compared to rats on a normal diet (table $1, \mathrm{p}<$ 0.05). High fructose-fed rats also exhibited elevated blood pressure (fig. $1, \mathrm{p}<0.001$ ), hypertriglyceridemia, hyperuricemia, and hyperinsulinemia (table $1, \mathrm{p}<0.05$ ) compared to normal controls. While serum glucose was similar, both the HOMA-IR and QUICKI indices documented insulin resistance in fructose-fed rats (fig. 2).

\section{Allopurinol and Captopril Effects on Metabolic \\ Syndrome}

Allopurinol treatment of fructose-fed rats partially prevented the rise in blood pressure (fig. $1, \mathrm{p}=0.01$ ) and hyperuricemia (table $1, \mathrm{p}<0.05$ ) compared to fructosefed rats but did not reduce abdominal obesity or serum triglycerides (table 1).

Captopril alone significantly reduced blood pressure (fig. $1, \mathrm{p}<0.001$ ), body weight (table $1, \mathrm{p}=0.02$ ) and abdominal obesity (table $1, \mathrm{p}<0.05)$. A trend for a decrease in serum triglycerides was also noted $(p=0.07)$.

\section{Combination of Captopril and Allopurinol Prevents}

Fructose-Induced Metabolic Syndrome

The F + C + A group showed the least features of metabolic syndrome compared to all other groups. Compared to $\mathrm{F}$ alone, captopril + allopurinol treatment was able to prevent the rise in blood pressure (fig. $1, \mathrm{p}<0.001$ ), significantly reduce body weight gain (table 1), and pre-

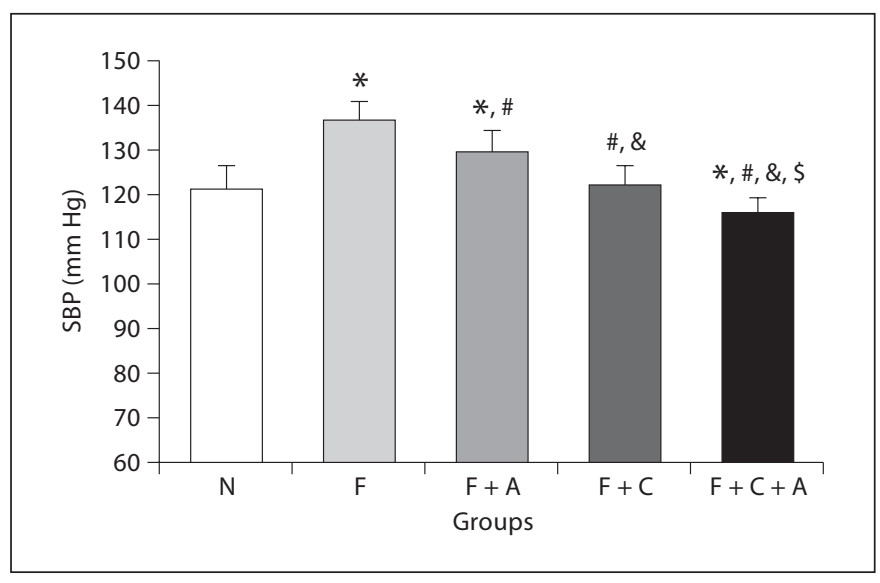

Fig. 1. Systolic blood pressure (SBP) at 7 weeks. $\mathrm{N}=$ Normal group; $\mathrm{F}=$ fructose group $\mathrm{F}+\mathrm{A}=$ fructose plus allopurinol group; $\mathrm{F}+$ $\mathrm{C}=$ fructose plus captopril group; $\mathrm{F}+\mathrm{C}+\mathrm{A}=$ fructose plus captopril plus allopurinol group. $\mathrm{p}<0.05^{*}$ vs. $\mathrm{N},{ }^{\#}$ vs. $\mathrm{F},{ }^{\&}$ vs. $\mathrm{F}+\mathrm{A}$, $\$$ vs. F + C.

vent the accumulation of abdominal fat (table 1). In addition, combined therapy significantly improved hypertriglyceridemia, hypercholesterolemia, and hyperuricemia (table $1, \mathrm{p}<0.05$ ). The $\mathrm{F}+\mathrm{C}+\mathrm{A}$ group also maintained normal serum insulin levels and insulin resistance was prevented (fig. 2, HOMA-IR and QUICKI, both $\mathrm{p}<$ $0.02)$.

Combination treatment had additional favorable effects compared to each treatment alone. For example, compared to $\mathrm{F}+\mathrm{C}, \mathrm{F}+\mathrm{C}+\mathrm{A}$ had lower SBP (fig. 1, $\mathrm{p}=$ 0.008 ), lower serum cholesterol (table $1, p=0.04$ ) and less 


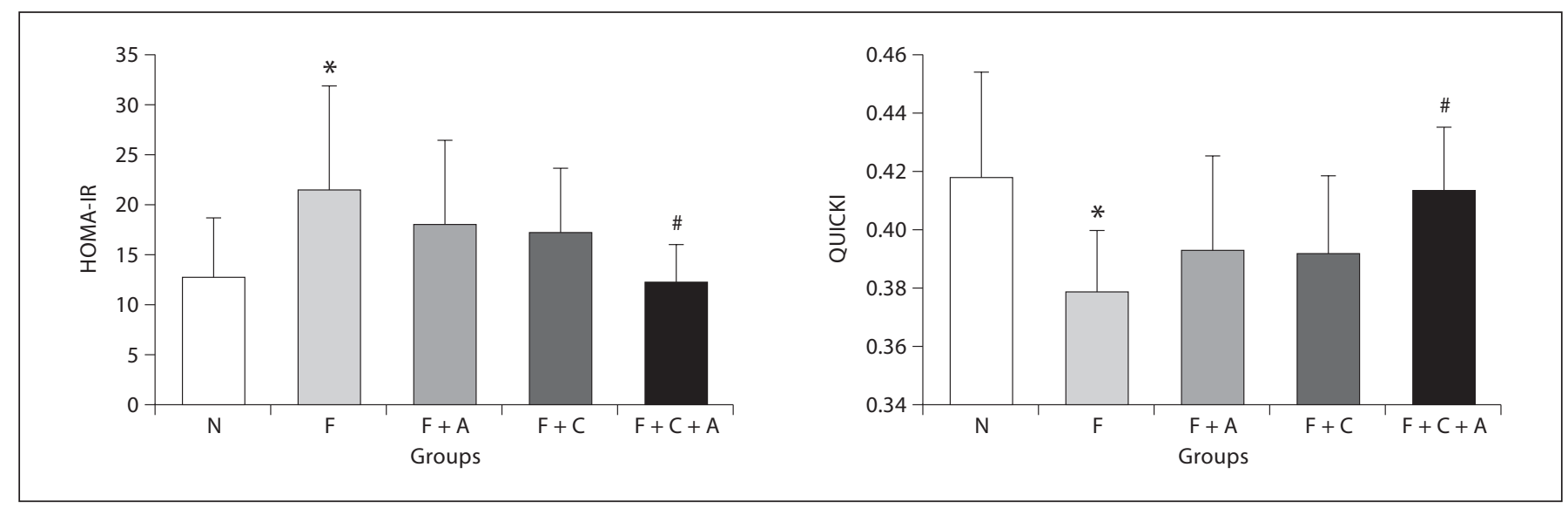

Fig. 2. Effect of combination therapy on insulin resistance. $N=$ Normal group; $F=$ fructose group; $F+A=$ fructose plus allopurinol group; $\mathrm{F}+\mathrm{C}=$ fructose plus captopril group; $\mathrm{F}+\mathrm{C}+\mathrm{A}=$ fructose plus captopril plus allopurinol group; HOMA-IR = homeostasis model assessment of insulin resistance; QUICKI = Quantitative Insulin Sensitivity Check Index. p $<0.05{ }^{*}$ vs. N, ${ }^{*}$ vs. F.

insulin resistance (fig. 2, HOMA-IR, $\mathrm{p}=0.08$ ). Addition of captopril also potentiated the effect of allopurinol on SBP (fig. $1, \mathrm{p}<0.001$ ), serum UA (table $1, \mathrm{p}=0.002$ ), and serum triglycerides (table $1, \mathrm{p}=0.03$ ).

\section{Discussion}

We determined if allopurinol has similar protective effects as ACE inhibitors in preventing fructose-induced metabolic syndrome, or whether the therapies are additive. Both blocking the RAS $[34,35]$ and lowering UA [5, 36] have already been reported to partially prevent fructose-induced metabolic syndrome in rats. However, lowering UA may work in part by blocking the RAS. UA activates the RAS both in vitro and in vivo $[12,37]$ and blocking the RAS reduces blood pressure and renal injury in hyperuricemic rats $[13,37]$. Hyperuricemia is also associated with elevated plasma renin activity in humans [15], and lowering UA in hypertensive adolescents lowers blood pressure with a fall in plasma renin activity [38]. Thus, we determined if the use of allopurinol was equivalent to using an ACE inhibitor or whether the two had synergistic actions.

The primary finding was that combination treatment was superior to either treatment alone. While captopril partially prevented metabolic syndrome, especially with regard to reducing blood pressure and intra-abdominal fat, it had minimal benefit on insulin resistance and hypertriglyceridemia. Allopurinol effectively lowered blood pressure but had no benefit on other metabolic parameters. In contrast, captopril and allopurinol in combination preserved normal blood pressure and insulin sensitivity and prevented hypertriglyceridemia, hyperuricemia, and hypercholesterolemia. The exploration of potential mechanisms that resulted in a superior effect of combined therapy will be evaluated in future studies.

A second and perhaps more interesting finding resulted from the study design. Specifically, it was important to assure equivalent energy intake to each group so that the benefit of treatment could not be attributed to differences in fructose intake. Prior studies have reported that ACE inhibitor treatment results in reduced food intake in rats [31], a finding we also confirmed. As a consequence, rats were forced to eat only $80 \%$ of their normal energy intake as compared to our previous study in which the high fructose diet was administered ad libitum [5]. Despite the restricted energy intake, the fructose-fed rats still developed many features of metabolic syndrome. Hence these studies document that the metabolic syndrome induced by fructose does not require excessive energy intake but can occur even with energy restriction.

Even though animals were pair-fed, captopril treatment (with or without allopurinol) reduced body weight compared to the other groups. This is consistent with reports that ACE inhibitors may increase metabolic efficiency [31] or may block angiotensin II-mediated adipocyte growth [39]. Furthermore, mice overexpressing angiotensinogen in adipose tissue display increased adiposity and plasma insulin levels compared to wild-type 
controls, whereas mice lacking angiotensinogen display opposite findings [40].

In previous studies we reported that lowering UA improves insulin resistance and dyslipidemia in fructoseinduced metabolic syndrome $[5,7]$, a finding that contrasts with the current report. Two possible explanations may account for these findings. We recently reported that rats fed fructose ad libitum chronically become leptin resistant [41], suggesting that one mechanism involved in fructose-induced metabolic syndrome may be via increased energy intake. It is possible that allopurinol acts more effectively under conditions in which diet is not restricted, or that its effect could be due to the prevention of leptin resistance. Second, fructose-induced hyperuricemia is maximal in the first few hours following ingestion of fructose [42-44] and is also dose dependent [45, 46]; thus, it is possible that the effect of UA on hyperinsulinemia and hypertriglyceridemia depend on both time of blood collection and total dose of fructose ingested.

In conclusion, fructose-induced metabolic syndrome can occur in the setting of energy restriction. Furthermore, we document that captopril and allopurinol are synergistic in their ability to prevent fructose-induced metabolic syndrome. Further studies are required to understand how these two drugs interact to provide superior protection to either drug alone. However, the importance of this study is that it suggests that combination allopurinol and ACE therapy might provide a potential superior therapeutic strategy to prevent diabetes and cardiovascular disease.

\section{Acknowledgements}

Support for the study was provided by US Public Health grants DK-52121 and HL-68607. S.R. is supported by a fellowship from the Anandamahidol Foundation of Thailand. L.G.S.-L. is supported by Grant 081054 from CONACYT, Mexico.

\section{Disclosure}

Dr. Reungjui, Dr. Nakagawa, and Dr. Johnson have applied for a patent with the University of Florida on combination treatment of allopurinol and ACE inhibitor for the treatment of features of metabolic syndrome based on this work.

\section{References}

1 Ford ES, Giles WH, Mokdad AH: Increasing prevalence of the metabolic syndrome among US adults. Diabetes Care 2004;27: 2444-2449.

-2 Bray GA, Nielsen SJ, Popkin BM: Consumption of high-fructose corn syrup in beverages may play a role in the epidemic of obesity. Am J Clin Nutr 2004;79:537-543.

-3 Stanhope KL, Schwarz JM, Keim NL, Griffen SC, Bremer AA, Graham JL, Hatcher B, Cox CL, Dyachenko A, Zhang W, McGahan JP, Seibert A, Krauss RM, Chiu S, Schaefer EJ, Ai M, Otokozawa S, Nakajima K, Nakano T, Beysen C, Hellerstein MK, Berglund L, Havel PJ: Consuming fructose-sweetened, not glucose-sweetened, beverages increases visceral adiposity and lipids and decreases insulin sensitivity in overweight/obese humans. J Clin Invest 2009;119:1322-1334

-4 Swarbrick MM, Stanhope KL, Elliott SS, Graham JL, Krauss RM, Christiansen MP, Griffen SC, Keim NL, Havel PJ: Consumption of fructose-sweetened beverages for 10 weeks increases postprandial triacylglycerol and apolipoprotein-B concentrations in overweight and obese women. Br J Nutr 2008;100:947-952.
5 Nakagawa T, Hu H, Zharikov S, Tuttle KR, Short RA, Glushakova O, Ouyang X, Feig DI, Block ER, Herrera-Acosta J, Patel JM, Johnson RJ: A causal role for uric acid in fructoseinduced metabolic syndrome. Am J Physiol Renal Physiol 2006;290:F625-F631.

6 Cirillo P, Gersch MS, Mu W, Scherer PM, Kim KM, Gesualdo L, Henderson GN, Johnson RJ, Sautin YY: Ketohexokinase-dependent metabolism of fructose induces proinflammatory mediators in proximal tubular cells. J Am Soc Nephrol 2009;20:457-459.

7 Sanchez-Lozada LG, Tapia E, Bautista-García P, Soto V, Vila-Casado C, Vega-Campos IP, Nakagawa T, Zhao L, Franco M, Johnson RJ: Effects of febuxostat on metabolic and renal alterations in rats with fructose-induced metabolic syndrome. Am J Physiol Renal Physiol 2008;294:F710-F718.

-8 Khosla UM, Zharikov S, Finch JL, Nakagawa T, Roncal C, Mu W, Krotova K, Block ER, Prabhakar S, Johnson RJ: Hyperuricemia induces endothelial dysfunction. Kidney Int 2005;67:1739-1742.

9 Kang DH, Park SK, Lee IK, Johnson RJ: Uric acid-induced C-reactive protein expression: implication on cell proliferation and nitric oxide production of human vascular cells. J Am Soc Nephrol 2005;16:3553-3562.
10 Sautin YY, Nakagawa T, Zharikov S, Johnson RJ: Adverse effects of the classic antioxidant uric acid in adipocytes: NADPH oxidasemediated oxidative/nitrosative stress. Am J Physiol Cell Physiol 2007;293:C584-C596.

-11 Zharikov SI, Krotova K, Hu H, Baylis C, Johnson RJ, Block ER, Patel JM: Uric acid decreases NO production and increases arginase activity in cultured pulmonary artery endothelial cells. Am J Physiol Cell Physiol 2008;295:C1183-C1190.

12 Corry DB, Eslami P, Yamamoto K, Nyby MD, Makino H, Tuck ML: Uric acid stimulates vascular smooth muscle cell proliferation and oxidative stress via the vascular renin-angiotensin system. J Hypertens 2008; 26:269-275.

13 Mazzali M, Hughes J, Kim YG, Jefferson JA, Kang DH, Gordon KL, Lan HY, Kivlighn S, Johnson RJ: Elevated uric acid increases blood pressure in the rat by a novel crystalindependent mechanism. Hypertension 2001;38:1101-1106

14 Sanchez-Lozada LG, Soto V, Tapia E, VilaCasado C, Sautin YY, Nakagawa T, Franco $\mathrm{M}$, Rodriguez-Iturbe B, Johnson RJ: Role of oxidative stress in the renal abnormalities induced by experimental hyperuricemia. Am J Physiol Renal Physiol 2008;295:F1134F1141. 
15 Saito I, Saruta T, Kondo K, Nakamura R, Oguro T, Yamagami K, Ozawa Y, Kato E: Serum uric acid and the renin-angiotensin system in hypertension. J Am Geriatr Soc 1978; 26:241-247.

-16 Andraws R, Brown DL: Effect of inhibition of the renin-angiotensin system on development of type 2 diabetes mellitus (meta-analysis of randomized trials). Am J Cardiol 2007;99:1006-1012.

-17 McFarlane SI, Kumar A, Sowers JR: Mechanisms by which angiotensin-converting enzyme inhibitors prevent diabetes and cardiovascular disease. Am J Cardiol 2003;91: $30 \mathrm{H}-37 \mathrm{H}$.

-18 Masuo K, Mikami H, Ogihara T, Tuck ML: Weight reduction and pharmacologic treatment in obese hypertensives. Am J Hypertens 2001; $14: 530-538$.

19 Tran LT, Yuen VG, McNeill JH: The fructose-fed rat: a review on the mechanisms of fructose-induced insulin resistance and hypertension. Mol Cell Biochem 2009; E-pub ahead of print.

-20 Tran LT, Macleod KM, McNeill JH: Endothelin-1 modulates angiotensin II in the development of hypertension in fructose-fed rats. Mol Cell Biochem 2009;325:89-97.

21 Cheng TH, Lin JW, Chao HH, Chen YL, Chen $\mathrm{CH}$, Chan P, Liu JC: Uric acid activates extracellular signal-regulated kinases and thereafter endothelin-1 expression in rat cardiac fibroblasts. Int J Cardiol 2008; E-pub ahead of print.

-22 Chao HH, Liu JC, Lin JW, Chen CH, Wu CH, Cheng TH: Uric acid stimulates endothelin-1 gene expression associated with NADPH oxidase in human aortic smooth muscle cells. Acta Pharmacol Sin 2008;29:1301-1312.

>23 Long CL, Qin XC, Pan ZY, Chen K, Zhang YF, Cui WY, Liu GS, Wang H: Activation of ATP-sensitive potassium channels protects vascular endothelial cells from hypertension and renal injury induced by hyperuricemia. J Hypertens 2008;26:2326-2338.

-24 Suzuki Y, Sudo J, Tanabe T: Allopurinol toxicity: its toxic organ-specificity between the liver and the kidney in the rat. J Toxicol Sci 1984;9:343-351.

-25 Trachtman H, Valderrama E, Futterweit S: Nephrotoxicity of allopurinol is enhanced in experimental hypertension. Hypertension 1991;17:194-202.
26 Megison SM, Horton JW, Chao H, Walker PB: High dose versus low dose enteral allopurinol for prophylaxis in mesenteric ischemia. Circ Shock 1990;30:323-329.

27 Assis SM, Monteiro JL, Seguro AC: L-Arginine and allopurinol protect against cyclosporine nephrotoxicity. Transplantation 1997;63:1070-1073.

28 Cahova M, Vavrinkova H, Tutterova M, Meschisvilli E, Kazdova L: Captopril enhanced insulin-stimulated glycogen synthesis in skeletal muscle but not fatty acid synthesis in adipose tissue of hereditary hypertriglyceridemic rats. Metabolism 2003;52:1406-1412.

-29 Bensaoula T, Ottlecz A: Biochemical and ultrastructural studies in the neural retina and retinal pigment epithelium of STZ-diabetic rats: effect of captopril. J Ocul Pharmacol Ther 2001;17:573-586.

30 Radin MJ, Wilke WL, Fettman MJ: Dose effect of captopril on renal hemodynamics and proteinuria in conscious, partially nephrectomized rats. Proc Soc Exp Biol Med 1989; 190:294-300.

31 Santos EL, de Picoli SK, Guimaraes PB, Reis FC, Silva SM, Costa-Neto CM, Luz J, Pesquero JB: Effect of angiotensin converting enzyme inhibitor enalapril on body weight and composition in young rats. Int Immunopharmacol 2008;8:247-253.

32 Pickavance LC, Brand CL, Wassermann K, Wilding JP: The dual PPARalpha/gamma agonist, ragaglitazar, improves insulin sensitivity and metabolic profile equally with pioglitazone in diabetic and dietary obese ZDF rats. Br J Pharmacol 2005;144:308-316.

33 Cacho J, Sevillano J, de Castro J, Herrera E, Ramos MP: Validation of simple indexes to assess insulin sensitivity during pregnancy in Wistar and Sprague-Dawley rats. Am J Physiol Endocrinol Metab 2008;295:E1269E1276.

34 Furuhashi M, Ura N, Takizawa H, Yoshida D, Moniwa N, Murakami H, Higashiura K, Shimamoto K: Blockade of the renin-angiotensin system decreases adipocyte size with improvement in insulin sensitivity. J Hypertens 2004;22:1977-1982.

-35 Oda T, Hirata M, Oshida Y, Han YQ, Koshinaka K, Sato Y: Effect of imidapril, an angiotensin-converting enzyme inhibitor, on fructose-induced insulin resistance in rats. Endocr J 2004;51:69-74.
36 Reungjui S, Roncal CA, Mu W, Srinivas TR, Sirivongs D, Johnson RJ, Nakagawa T: Thiazide diuretics exacerbate fructose-induced metabolic syndrome. J Am Soc Nephrol 2007;18:2724-2731.

37 Mazzali M, Kanellis J, Han L, Feng L, Xia YY, Chen Q, Kang DH, Gordon KL, Watanabe S, Nakagawa T, Lan HY, Johnson RJ: Hyperuricemia induces a primary renal arteriolopathy in rats by a blood pressure-independent mechanism. Am J Physiol Renal Physiol 2002;282:F991-F997.

38 Feig DI, Soletsky B, Johnson RJ: Effect of allopurinol on blood pressure of adolescents with newly diagnosed essential hypertension: a randomized trial. JAMA 2008;300: 924-932.

-39 Engeli S, Negrel R, Sharma AM: Physiology and pathophysiology of the adipose tissue renin-angiotensin system. Hypertension 2000; 35:1270-1277.

40 Kim S, Soltani-Bejnood M, Quignard-Boulange A, Massiera F, Teboul M, Ailhaud G, Kim JH, Moustaid-Moussa N, Voy BH: The adipose Renin-Angiotensin system modulates systemic markers of insulin sensitivity and activates the intrarenal renin-angiotensin system. J Biomed Biotechnol 2006;2006: 27012.

41 Shapiro A, Mu W, Roncal C, Cheng KY, Johnson RJ, Scarpace PJ: Fructose-induced leptin resistance exacerbates weight gain in response to subsequent high-fat feeding. Am J Physiol Regul Integr Comp Physiol 2008; 295:R1370-R1375.

42 Perheentupa J, Raivio K: Fructose-induced hyperuricaemia. Lancet 1967;2:528-531.

$\checkmark 43$ Fiaschi E, Baggio B, Favaro S, Antonello A, Camerin E, Todesco S, Borsatti A: Fructoseinduced hyperuricemia in essential hypertension. Metabolism 1977;26:1219-1223.

44 Stirpe F, Della Corte E, Bonetti E, Abbondanza A, Abbati A, De Stefano F: Fructoseinduced hyperuricaemia. Lancet 1970;2: 1310-1311.

-45 Gao X, Qi L, Qiao N, Choi HK, Curhan G, Tucker KL, Ascherio A: Intake of added sugar and sugar-sweetened drink and serum uric acid concentration in US men and women. Hypertension 2007;50:306-312.

46 Heuckenkamp PU, Zollner N: Fructose-induced hyperuricaemia. Lancet 1971;1:808809 . 